\title{
PENGAYAAN NILAI NUTRITIF SEKAM PADI BERBASIS BIOTEKNOLOGI “EFFECTIVE MICROORGANISMS”' (EM4) SEBAGAI BAHAN PAKAN ORGANIK.
}

\author{
Chandra Telew *), V.G Kereh **), I.M Untu**) dan B.W. Rembet **) \\ Fakultas Peternakan Universitas Sam Ratulangi Manado, 95115. \\ email: chandratlw@yahoo.com
}

\begin{abstract}
ABSTRAK
Suatu penelitian telah dilakukan untuk melihat sejauh mana pengayaan nilai nutritif sekam padi berbasis bioteknologi "Effective Microorganisms" (EM4). Penelitian ini telah dilaksanakan di Laboratorium Teknologi Pengolahan dan Industri Makanan Ternak Fakultas Peternakan UNSRAT, kemudian dilanjutkan dengan analisis sampel di Laboratorium BARISTAND (Badan Riset dan Standarisasi Industri) Sulut. Lamanya penelitian dari bulan September sampai November 2011. Penelitian ini menggunakan metode eksperimen dengan pola Rancangan Acak Lengkap (RAL) yang terdiri dari 3 perlakuan dan 5 ulangan, dengan perlakuan sebagai berikut, yaitu ; $\mathrm{R}_{0}$ : Sekam Padi non Rekayasa (SPnR), $\mathrm{R}_{1}$ : Sekam Padi Rekayasa EM + $2500 \mathrm{ml}$ air (SPRns), $\mathrm{R}_{2}$ : Sekam Padi Rekayasa EM + $2500 \mathrm{ml}$ cuka saguer (SPRps). Variabel yang diukur yaitu nilai nutritif sekam padi meliputi protein, serat kasar, dan energi sekam padi non rekayasa dan rekayasa dengan EM4. Hasil yang diperoleh dari penelitian ini menunjukan bahwa sekam padi yang direkayasa dengan EM4 mengalami peningkatan kadar protein dari $1,92 \%$ menjadi $2,67 \%$ atau terjadi kenaikan sebesar 39\%, sedangkan rekayasa EM4 + cuka saguer kadar proteinnya menjadi $2,22 \%$ (terjadi kenaikan $15 \%$ ). Untuk serat kasar terjadi penurunan dari $37,33 \%$ menjadi $13,02 \%$, sedangkan rekayasa dengan EM4 + cuka
\end{abstract}

\footnotetext{
* Alumni Fakultas Peternakan

** Jurusan Nutrisi dan Makanan Ternak
}

saguer menjadi $13,24 \%$. Kemudian untuk kadar energi terlihat bahwa sekam padi yang direkayasa dengan EM4 menghasilkan peningkatan kadar energi dari 302,33 KKal/Kg menjadi 375,62 $\mathrm{KKal} / \mathrm{Kg}$ atau terjadi kenaikan sebesar 24\%, sedangkan untuk sekam padi rekayasa EM4 + cuka saguer kadar proteinnya menjadi $373.08 \mathrm{KKal} / \mathrm{Kg}$. Hasil analisis keragaman menunjukan bahwa sekam padi yang difermentasi dengan EM4 memberikan pengaruh berbeda sangat nyata $(\mathrm{P}<0,01)$. Dari penelitian yang telah dilakukan diambil kesimpulan bahwa bahwa rekayasa sekam padi dengan "EM4" terjadi pengayaan nilai nutritif sekam padi yang ditandai dengan turunnya kadar serat kasar dan meningkatnya kadar protein dan energi.

Kata Kunci: Sekam padi, Nilai nutritif, Effective microorganisms (EM4).

\section{ABSTRACT}

THE IMPROVEMENT OF THE RICE HUSKS NUTRITIONAL VALUE WITH A BIOTECHNOLOGY "EFFECTIVE MICROORGANISMS" (EM4) AS AN ORGANIC FEED INGREDIENT. A research has been conducted to see how far the improvement of the nutritional value of the rice husk with a biotechnology "Effective Microorganisms" (EM4). The research has been conducted in the feed processing laboratory, Faculty of Animal Husbandry, Sam Ratulangi University, and continued with a sample analysis in the BARISTAND Laboratorium. The duration of this research is from September until November 2011. This research uses the completely randomized 
design (CRD) that is comprised with 3 treatments and 5 repetitions, with treatments : $\mathrm{R}_{0}$; Rice husk non-modified (SPnR), $\mathrm{R}_{1}$; Rice husk modified with $\mathrm{EM}+2500 \mathrm{ml}$ of water, $\mathrm{R}_{2}$ Rice husk modified with EM+2500 of saguer vinegar (SPRps). The variables that is measured is the nutritional value of the rice huskwhich comprises of protein, crude fiber, and energy of the non modified rice husks and the EM4 modified rice husks. The results of this research shows that rice husk that are modified with EM4 experienced a protein increase of $1.92 \%$ to $2.67 \%$ or an increase of $39 \%$, while the rice husk that are modified with EM4 has an amount of protein of $2.22 \%$ (an increase of $15 \%$ ). These has been a decrease of the amount of crude fibre from $37.33 \%$ to $13.24 \%$. next, for the amount energy shows that the rice husks that were modified with EM4 resulted with an increase of the amount of energyfrom $302.33 \mathrm{kkal} / \mathrm{kg}$ to $375.62 \mathrm{kkal} / \mathrm{kg}$ or an increase of $24 \%$, while the rice husk that were modified with EM4+saguer vinegar the amount of the protein was $373,08 \mathrm{kkal} / \mathrm{kg}$. The results of the variants analysis showed that the rice husks that were fermented with EM4 had an effect of a real difference $(\mathrm{P}<0,01)$. From the conducted research we can conclude that the modification of the rice husks with EM4 aparently gave an improvement on the nutritional value of the rice husks that is marked with the decrease of crude fibre and an increase of the amount of protein and energy.

\section{Keywords: Rice husks, Effective Microorganisms (EM4) and Nutritional Value.}

\section{PENDAHULUAN}

Potensi industri peternakan di Indonesia sangat besar namun sering dibatasi oleh masalah pakan yang harganya relatif mahal dan ketersediaannya kurang stabil, sebagai akibat dari masih terjadinya kompetisi dengan pangan. Strategi yang harus ditempuh adalah memanfaatkan bahan baku pakan yang tidak digunakan untuk pangan. Di Indonesia termasuk Sulawesi Utara, bahan baku yang mempunyai potensi besar sebagai pakan adalah limbah dan hasil samping dari usaha pertanian seperti jerami, dedak dan sekam padi. Hasil survai Biro Pusat Statistik Sulawesi Utara tahun 2009 untuk produksi padi 549.087 ton meningkat pada tahun 2010 menjadi 583.458 ton, dengan luas areal tanaman 119.626 hektar. Hal itu berarti sekam padi senantiasa tersedia sepanjang tahun dalam jumlah yang cukup besar dan tidak dimanfaatkan sebagai bahan pangan.

Sekam padi mempunyai potensi menjadi bahan pakan karena: (1) Produksinya tinggi,

Penggunaannya tidak bersaing dengan kebutuhan manusia, (3) Masih belum banyak dipergunakan untuk tujuantujuan lain yang lebih bernilai ekonomi sehingga hanya terbuang atau dibakar langsung, (4) Keberadaannya terkonsentrasi pada tempat tertentu (di pabrik penggilingan padi) sehingga memudahkan pengumpulannya, (5) Kontinuitas ketersediaan terjamin karena seiring dengan produk utamanya berupa beras.

Kendala utama dari sekam padi sebagai salah satu bahan pakan yaitu nilai nutritifnya rendah, ditandai oleh kandungan serat kasar tinggi, protein dan energi rendah. Penggunaan sekam padi secara langsung atau sebagai pakan tunggal tidak dapat memenuhi asupan yang sesuai dengan kebutuhan ternak. Close dan Menke (1986), menyatakan rendahnya kecernaan 
sekam padi antara lain disebabkan oleh tingginya kandungan silika dan lignin serta adanya ikatan lignoselulosa, dan jika dikonsumsi oleh ternak akan sulit untuk dicerna bahkan dapat menimbulkan gangguan pencernaan dan produksi ternak. Untuk mengatasi hal tersebut dapat dilakukan dengan menggunakan jasa mikroba melalui proses bioteknologi fermentasi.

Bioteknologi fermentasi saat ini perkembangannya cukup pesat baik dalam bidang pertanian maupun peternakan mengingat peranannya dalam peningkatan produksi cukup besar. Bioteknologi fermentasi pada prinsipnya dapat menaikkan kualitas bahan berserat tinggi, baik oleh adanya penyederhanaan fraksi serat kasar menjadi komponen dasar energi tersedia maupun protein sel tunggal yang berasal dari multiplikasi biomassa sel mikroorganisme. Salah satu bioteknologi fermentasi yang dapat digunakan ialah bioteknologi "Effective Microorganisms" (EM)

Bioteknologi "EM" adalah suatu sistem bioteknologi yang ditemukan pertama kali oleh Prof. Dr. Teruo Higa dari Universitas Ryukyu Okinawa Jepang sekitar tahun 1980-an (Permana, 1997). Pada awalnya teknologi ini diperkenalkan kepada petani untuk memperbaiki kondisi tanah, menekan pertumbuhan mikroba yang menimbulkan penyakit dan meningkatkan efisiensi penggunaan bahan organik oleh tanaman (Higa, 1996). Larutan EM merupakan suatu kultur campuran berbagai mikroorganisme yang bermanfaat terutama Lactobacillus, bakteri fotosintetik, actynomycetes, ragi dan jamur fermentasi. Teknologi ini terbukti dapat memperbaiki kualitas tanah, memperbaiki pertumbuhan serta jumlah dan mutu hasil tanaman. Dalam bidang peternakan teknologi ini dapat di gunakan untuk memperbaiki nilai nutrisi limbah pertanian, dan bahan yang kurang berdaya guna untuk dijadikan bahan pakan.

Berdasarkan uraian diatas maka telah dilakukan penelitian terhadap sekam padi untuk melihat seberapa besar pengayaan nilai nutrisinya yang direkayasa dengan bioteknologi EM, sehingga menjadi salah satu bahan pakan organik yang lebih berkualitas.

\section{MATERI DAN METODE PENELITIAN}

Penelitian ini telah dilaksanakan di Laboratorium Teknologi Pengolahan dan Industri Makanan Ternak Fakultas Peternakan UNSRAT sejak tanggal 1 sampai tanggal 6 Oktober 2011 kemudian dilanjutkan dengan analisis sampel di Laboratorium BARISTAND (Badan Riset dan Standarisasi Industri) Sulut pada tanggal 7 sampai 21 Oktober 2011.

Peralatan yang digunakan adalah timbangan Ohaus, timbangan analitikgelas ukur $100 \mathrm{ml}$, termometer batang, pH meter, loyang plastik, pisau, kantong plastik, karung plastik, wadah untuk proses biofermentasi yang terbuat dari kayu berukuran $1 \mathrm{~m}$ x $1 \mathrm{~m} \quad \mathrm{x} \quad 15 \mathrm{~cm}$. Substrat yang direkayasa dengan bioteknologi EM4 adalah sekam padi. Bahan-bahan lain yang digunakan adalah; dedak kasar jagung, gula aren, asam asetat teknis (cuka saguer) dan air. Penggunaan bahan cuka saguer adalah sebagai pelarut pada SPRps, sedangkan untuk 
gula aren berfungsi untuk mengaktifkan kerja mikroba.

Penelitian ini menggunakan metode eksperimental berdasarkan Rancangan Acak Lengkap menurut Steel and Torrie (1991) yang terdiri dari 3 perlakuan dan 5 ulangan dengan perlakuan sebagai berikut :

Ro : Sekam Padi non Rekayasa (SPnR)

R1 : Sekam Padi Rekayasa EM + $2500 \mathrm{ml}$ air (SPRns)

R2 : Sekam Padi Rekayasa EM + $2500 \mathrm{ml}$ cuka saguer (SPRps)

Tata laksana penelitian:

1. Prinsip perekayasaan substrat berbasis "EM"

Prosedur pembuatan bokashi mengikuti petunjuk Higa (1996) dalam Rembet (1999) dengan ilustrasi sebagai berikut:

- Substrat limbah/sekam padi 2,5 $\mathrm{Kg}$

- Dedak kasar jagung 2,5 Kg

- Gula aren 250 gr

- Larutan EM $25 \mathrm{ml}$

- Pelarut (Air) $2500 \mathrm{ml}$

- Pelarut Cuka Saguer (khusus SPRns) $2500 \mathrm{ml}$

Pemakaian cuka saguer dimaksudkan untuk mempercepat proses fermentasi, mengingat bakteri menyukai keadaan yang asam. Kondisi pertumbuhan ideal bagi mikroba: Suhu $35^{\circ}$ sampai $45^{\circ} \mathrm{C}$; Masa inkubasi 4 hari; hal ini dimaksudkan karena substrat yang dipakai memiliki kadar serat kasar yang tinggi.

2. Tahapan penelitian

a. Timbang/ukur sekam padi, dedak kasar jagung yang telah ditetapkan dan dicampur merata. b. Larutkan gula aren yang telah dihaluskan dalam air panas suhu \pm $50^{\circ} \mathrm{C}$

c. Tuangkan larutan gula aren ke dalam wadah berisi pelarut yang sudah diukur.

d. Tuangkan larutan EM4 ke dalam larutan butir c, lalu aduk hingga merata.

e. Tuangkan larutan butir 4 secara bertahap ke substrat (butir 1) lalu digodok sehomogen mungkin.

f. Pindahkan bahan yang sudah dicampur ke dalam biofermentor beralas ubin, tutup rapat-rapat dengan karung plastik, didahului dengan mengukur $\mathrm{pH}$ awal dan suhu awal dari substrat yang diteliti.

g. Lama jangka waktu inkubasi 4 hari. Bila kondisi anaerobik dipertahankan suhu cenderung akan naik. Suhu yang ideal adalah 35 $45^{\circ} \mathrm{C}$, oleh sebab itu bila suhu sudah naik mendekati $50^{\circ} \mathrm{C}$ adonan perlu dibongkar dengan maksud mempertahankan suhu ideal. Perubahan suhu dideteksi setiap 6 jam sampai proses inkubasi fermentasi selesai, ditandai penurunan suhu secara teratur.

h. Substrat bahan yang sudah terfermentasi disebarkan di lantai dalam ruangan yang teduh dianginanginkan sekitar setengah jam kemudian dimasukkan kedalam kantong plastik yang sudah diberi label (kode ; SPnr, SPRns, SPRps).

Parameter yang diukur dalam penelitian ini yaitu nilai nutritif meliputi protein, serat kasar dan gross energi sekam padi baik yang non rekayasa maupun terekayasa. 


\section{HASIL DAN PEMBAHASAN}

Penelitian tentang pengaruh pengayaan terhadap kandungan protein kasar, serat kasar dan gross energi sekam padi berbasis bioteknologi EM sebagai bahan pakan organik dapat dilihat pada Tabel 1 . Pada Tabel tersebut terlihat bahwa rataan kadar protein, serat kasar, gross energi dari setiap perlakuan menunjukan hasil yang berbeda terutama pada sekam padi yang non rekayasa dengan yang direkayasa dengan selisih kadar protein $0,75 \%$ (SPRns) dan 0,3 \% (SPRps), yang artinya telah terjadi peningkatan nilai nutritif. Hal ini sesuai dengan pendapat Winarno (1980), menyatakan bahwa bahan makanan yang mengalami fermentasi mempunyai nilai gizi yang lebih tinggi dibandingkan dengan bahan asalnya.

\section{Pengaruh Perlakuan terhadap Pengayaan Protein Sekam Padi}

Pada Tabel 1 terlihat, sekam padi yang direkayasa dengan "EM4" menghasilkan peningkatan protein dari $1,92 \%$ menjadi $2,67 \%$, sedangkan sekam padi rekayasa EM4 + cuka saguer kadar proteinnya menjadi $2,22 \%$.

Hasil analisis sidik ragam menunjukkan bahwa rekayasa dengan EM4 maupun EM4 + cuka saguer memberikan pengaruh yang berbeda sangat nyata $(\mathrm{P}<0,01)$ terhadap kadar protein substrat yang berarti kadar protein sekam padi rekayasa lebih tinggi disbanding kadar protein sekam padi non rekayasa. Hal ini menunjukkan sekam padi yang difermentasi dengan EM4 memberikan pengaruh nyata lebih tinggi dibandingkan dengan yang tidak difermentasi, karena pada saat fermentasi berlangsung terjadi peningkatan jumlah massa sel mikroba. Peningkatan tersebut terjadi karena dalam proses fermentasi mikroba menghasilkan sel mikrobia berupa protein sel tunggal, enzim mikrobia dan hasil metabolisme mikrobia yaitu asam amino, nukleotida, dan protein. Hal ini sejalan dengan pendapat Judoamidjojo dkk. (1989), bahwa dalam proses fermentasi akan terjadi peningkatan jumlah massa sel yang nantinya akan meningkatkan kadar protein dalam substrat.

Tabel 2. Rataan Kandungan Protein Kasar, Serat kasar, Gross Energi Sekam Padi

\begin{tabular}{|c|c|c|c|}
\hline \multirow{2}{*}{ Variabel yang diamati } & \multicolumn{3}{|c|}{ Perlakuan } \\
\hline & SPnR & SPRns & SPRps \\
\hline Protein Kasar (\%) & $1.92^{\mathrm{a}}$ & $2.67^{\mathrm{b}}$ & $2.22^{\mathrm{c}}$ \\
\hline Serat Kasar (\%) & $37.33^{\mathrm{a}}$ & $13.02^{\mathrm{b}}$ & $13.24^{\mathrm{c}}$ \\
\hline $\begin{array}{l}\text { Gross Energy } \\
(\mathrm{KKal} / \mathrm{Kg})\end{array}$ & $302.33^{\mathrm{a}}$ & $375.62^{\mathrm{b}}$ & $373.08^{\mathrm{c}}$ \\
\hline \multicolumn{4}{|c|}{ Keterangan: Superskrip yang berbeda kearah baris menunjukkan perbedaan yang nyata $(P<0,05)$} \\
\hline \multicolumn{2}{|c|}{ Hasil penelitian Syamsu (2006) } & mikrc & umum \\
\hline Yunilas & (2009) & meml & peningkatan kualitas \\
\hline $\begin{array}{l}\text { menggambarkan bah } \\
\text { nutrisi jerami padi } \\
\text { difermentasi menggu }\end{array}$ & $\begin{array}{c}\text { va komposisi } \\
\text { yang telah } \\
\text { nakan starter }\end{array}$ & $\begin{array}{l}\text { diban } \\
\text { diferr } \\
\text { kadar }\end{array}$ & $\begin{array}{l}\text { ni padi yang tidak } \\
\text { lanjutnya dilaporkan, } \\
\text { sar yang difermentasi }\end{array}$ \\
\hline
\end{tabular}


mengalami peningkatan dari $4,23 \%$ menjadi $8,14 \%$ dan diikuti dengan penurunan kadar serat kasar.

\section{Pengaruh Perlakuan terhadap} Penurunan Serat Kasar Sekam Padi

Pada Tabel 1 terlihat bahwa sekam padi yang direkayasa dengan EM4 menghasilkan penurunan kadar serat kasar dari $37,33 \%$ menjadi $13,02 \%$, sedangkan untuk sekam padi yang direkayasa dengan EM4 + cuka saguer menjadi 13,24\%. Hasil analisis sidik ragam menunjukan bahwa sekam padi yang direkayasa dengan EM4 maupun yang ditambahkan cuka saguer memberikan pengaruh yang berbeda sangat nyata $(\mathrm{P}<0,01)$ terhadap penurunan kadar serat kasar sekam padi.

Bahan atau substrat selulolitik seperti sekam padi yang sifatnya higroskopis ketika dicampur dengan larutan EM4, air, dan gula aren terjadi pembengkakan (swelling) dan pelonggaran (enlarge) sel substrat sehingga memudahkan mikroba yang terdapat dalam larutan EM4 masuk kedalam substrat untuk berkembang, bertumbuh dan bekerja sesuai dengan fungsi masing-masing organisme. Mikroba selulolitik menggunakan selulosa sebagai sumber energi dan karbon dengan cara menghasilkan enzim selulase yang dapat merombak dan mendegradasi komponen selulosa dan turunannya yang panjang menjadi glukosa (Hardjo dkk., 1989), lanjut dikatakan bahwa mikroba selulolitik berkemampuan dalam penggunaan substrat berserat karena mampu menghasilkan enzim selulase yang mampu mengurai selulosa menjadi glukosa.
Penurunan kadar serat kasar substrat rekayasa, karena dalam proses fermentasi terjadi pemecahan selulosa menjadi glukosa oleh enzim selulase juga dapat menghasilkan oligosakarida, disakarida atau trisakarida seperti selobiosa dan selotriosa, monomer glukosa atau produk pemecahan yang lainnya (alkohol, aldehida, keton, lisin dan vitamin) atau pada akhirnya karbondioksida $\left(\mathrm{CO}_{2}\right)$ dan air (Hardjo, dkk., 1989).

Hasil penelitian Rembet (1999) menyatakan bahwa substrat selulolitik (serbuk gergaji) yang difermentasi dengan EM4 memperlihatkan penurunan nilai serat kasar yang cukup signifikan, yakni dari 71,25\% menjadi 27,25. Kemudian hasil penelitian Komalig (2008) menyatakan bahwa jerami jagung yang difermentasi dengan EM4 mengalami penurunan kadar serat kasar dari 34,59\% menjadi 7,09\%. Hal ini menandakan bahwa EM4 sangat efektif dalam menurunkan kadar serat kasar.

\section{Pengaruh Perlakuan terhadap Pengayaan Energi Sekam Padi}

Berdasarkan data pada Tabel 1 terlihat bahwa sekam padi yang direkayasa dengan EM4 menghasilkan peningkatan kadar energi yaitu dari $302,33 \mathrm{KKal} / \mathrm{Kg}$ menjadi 375,62 $\mathrm{KKal} / \mathrm{Kg}$ sedangkan untuk sekam padi rekayasa EM4 + cuka saguer kadar proteinnya menjadi $373.08 \mathrm{KKal} / \mathrm{Kg}$.

Hasil analisis sidik ragam menunjukan bahwa rekayasa dengan EM4 maupun EM4 + cuka saguer memberikan pengaruh yang berbeda sangat nyata $(\mathrm{P}<0,01)$ terhadap kadar energi substrat yang berarti kadar 
energi sekam padi rekayasa lebih tinggi dibanding kadar energi sekam padi non rekayasa. Hal ini menunjukkan bahwa sekam padi yang difermentasi dengan EM4 memberikan pengaruh nyata lebih tinggi dibandingkan dengan yang tidak direkayasa. Peningkatan ini disebabkan oleh adanya mikroba selulolitik yang mampu memecah atau menguraikan komponen kompleks selulosa menjadi glukosa. Degradasi terhadap selulosa memberikan pengaruh terhadap nilai energi, hal ini disebabkan glukosa merupakan suatu senyawa yang mempunyai nilai manfaat sebagai bahan dasar energi siap pakai/mudah dicerna).

Hasil penelitian Ohy (2008) menggambarkan bahwa kulit jagung yang difermentasi dengan EM4 mengalami peningkatan nilai energi yakni dari 1556,7 kkal menjadi 2057,0 kkal. Hal ini menandakan bahwa pengayaan substrat selulolitik dengan menggunakan teknologi EM4 sangat efektif untuk meningkatkan kadar energi

\section{KESIMPULAN}

Berdasarkan hasil penelitian rekayasa sekam padi dengan "Effective Microorganisms" (EM4), terjadi pengayaan nilai nutrisi yang ditandai dengan meningkatnya kadar protein dan energi serta turunnya kadar serat kasar terutama pada sekam padi rekayasa $\mathrm{EM}+2500 \mathrm{ml}$ air (SPRns).

\section{SARAN}

1. Perlu penelitian lebih lanjut terhadap pengaruh penggunaan sekam padi yang direkayasa melalui bioteknologi "EM" sebagai bahan pakan organik alternatif pada ternak.

2. Perlu dilakukan penelitian lebih lanjut terhadap pelarut cuka saguer ketika di campurkan ke substrat agar di dapat waktu yang tepat sehingga fermentasi dapat berlangsung lebih ideal.

\section{DAFTAR PUSTAKA}

Badan Litbang Pertanian. 2008. Sekam Padi Sebagai Sumber Energi Alternatif dalam Rumah Tangga Petani.http://www.litbang.dept an.go.id/artikel/one/210/.

Diakses Tanggal 7 September 2011

Close, W. and K.H. Menke. 1986. Selected Topics in Animal Nutrition. A Manual Prepared for The Third Hohenheim Course on Animal Nutrition in The Tropics and Semi-Tropics. 2nd Ed. The Institute of Animal Nutrition, Hohenheim University, Stuttgart.

Hardjo, S., S. Indrasti dan T. Bantacut, 1989.

Biokonversi

Pemanfaatan Limbah Industri Pertanian. PAU. Pangan dan Gizi IPB. Bogor.

Higa, T, 1996. An Earth Saving Revolution, A Means to Resove Our World System Problem througs effective Microorganisms (EM). Publ, by Sunmark Publishing Inc. Sunmark Bldg, 1-3213.Takadanobaba.Shinyukuku. Tokyo. Japan. 
Khusuma, J. 2002. Pengaruh penggunaan serbuk gergaji yang direkayasa melalui bioteknologi "Effective Microorganisms" sebagai pengganti sebagian ransum itik layer lokal. Skripsi. Fapet Unsrat. Manado.

Permana, H. 1997. Pengolahan Limbah pertanian Dengan EM4. Makalah Program Pasca Sarjana UNPAD. Bandung.

Prasetyo, A. 2009. Fermentasi jerami untuk pakan ternak. http://indarto79.wordpress.com /2009/02/07/fermentasi-jeramiuntuk-pakan-ternak/. Diakses Tanggal 7 September 2011

Rembet, B.W. 1999, Rekayasa Nilai Nutritif Pakan Melalui Bioteknologi "Solid State Fermentation" dan "Effective Microorganisms" (Bokashi). Makalah Aplikasi paket Teknologi Pertanian. Fakultas Peternakan Unsrat. Manado.

Shiddieqy M. Ikhsan. 2010. Teruo Higa Penemu Teknologi EM. http://www.em4indonesia.com/ artikel/artikel-harianumum/teruo-higa-penemuteknologi-em. Diakses Tanggal 7 September 2011

Smith, E.J. 1993. Prinsip Bioteknologi. Penerbit PT. Gramedia. Jakarta.

Winarno, F.G. dan S. Fardiaz, 1990. Biofermentasi dan Biosintesa Protein. PT. Angkasa. Bandung. 